Historic, Archive Document

Do not assume content reflects current scientific knowledge, policies, or practices. 



\title{
THE CO-OPERATOR
}

\author{
ISSLED FREQUENTLY BY \\ The Bonnewitz Wholesale Gardens, Van Wert, Ohio
}

\section{A Favorite Recipe}

"Take a bit of cheerful thinking.

Add a portion of content,

And with both let glad endeavor.

Mixed with earnestness, be blent;

These with care and skill compounded.

Will produce a magic oil

That is bound to cure, if taken

With a lot of honest toil."

\section{-WATERMAN.}

I frequently glance through my wife's recipe file at the different mixtures which eventually make angel food, devil's food, caramel and white cake, various salads for beauty and taste, soups, oyster stews, pancakes, waffles and what not-but in the entire repertorium there is not a receipe more valuable than the one I have quoted, and I am giving it space in this issue of THE CO-OPERATOR in the hope that it may help others as it has helped me, to face a strenuous schedule with a cheerful, expectant attitude. We, as growers, have a seemingly stupendous task to educate the public and the various sales organizations supplying its needs, to appreciate the beauty and value of the newer Irises and Peonies, but a cheerful, hopeful attitude, blended with a true spirit of co-operation, will do wonders. Let's all push forward to that goal-a wider market for our favorites.

\section{Merchandising}

Your clothier, your grocer, your shoe-dealer. your butcher, in fact your merchant in almost any line, spends very little time and space manufacturing the merchandise he sells. However, he does know where the material can be purchased advantageously and quickly, and he realizes the importance of proper display. His service is to ascertain the merchandise his trade needs, to educate it at all times, to appreciate quality and service, and you know that he realizes a nice profit for his efforts. You also know that he can give his customer better goods and a wider range of choice, that if he tried to be the manufacturer and distributor, as well as the retailer of the merchandise he sells. Why not apply the same practical idea to Peony and Iris sales?
Develop a good display of Peonies and Irises in the right location, be a good stock-keeper of the planting, give the plants the proper background, the right cultivation and care, and secure the stock from a reliable source for your orders which are sure to develop when the public sees your planting in bloom. Be a good merchandiser. Little space and investment are required, and we are confident the returns will be satisfactory. Think it over. We are always ready to help.

\section{Character Studies}

An individual is judged by his character. Men place responsibilities, firms give positions, bankers make loans, in many instances, all on character. A man's character is in fact a summary of what people know about him. If he is honest, industrious, generous and broad-minded, his character rating is high, and he is acclaimed an exemplary citizen. And yet how easy it is to discount that character rating. One sometimes hears rumors, misunderstandings and seemingly unexplainable circumstances which reflect on the character of a good man, and it often takes years of effort, periods of heart-aches and untold sacrifices to regain the former high stanc. ing.

How similar is the position of an Iris, a Peony or in fact any other flower. Its size, its beauty, its form, its foliage, its growing habit, all establish a reputation for it which determines its character standing or true worth usually represented by its retail price. Through misunderstandings of growing conditions, of available stock or even trade demand, actions are some. times taken by growers which seriously reflect on the character or true worth of the flower, and as a result the retail nrice (which is the world's estimate of its worth) is rapidly lowered, and it soon wends its way into the group of neglected and unappreciated things. It may be that the flower will have sufficient outstanding quality and worth to withstand these slights of unrecognized merit, and eventually regain its former position of value-but it takes time and a lot of educational propaganda, all because someone did not carefully weigh its true value. It is important to consider carefully what we say about a friend and not cast any unfair reflection on his 


\section{THE CO-OPERATOR}

real character and worth. In the same way it is vitally important that we consider carefully any merchandising program that will reflect on the true worth of a flower. Study carefully the field, and decide on some sales plan that will allow each flower to maintain its fair value or true worth.

In many cases cuts are made on retail prices which would not be at all necessary, if the stock were known to be available. It could no doubt be absorbed by dealers and growers in territory where its real value is appreciated. Just as you would protect the character of a friend. you should assist every flower of merit to maintain its value or true worth. Give every good thing a fair deal.

\section{Stability of Prices}

We have had some most interesting reactions from the first installment of Mr. Bonnewitz's Iris Price List Rehearsal given in the first issue of THE CO-OPERATOR, and in recognition of these responses we are giving another installment of Mr. Bonnewitz's comments on our Iris List now in preparation. A few people misinterpreted our intention by thinking the rehearsal was an effort on our part to form a growers' combination to "hold up" prices. I want to say as emphatically as I can say it in print-This never entered out minds. As an organization we want to carry our price on each variety as low as the quality and quantity of stock will warrant, and our sole aim in the Iris Price List rehearsal is to broadcast our opinion of the merits and trade value of the different varieties.

The question of price naturally resolves itself into a decision on a urinitie sales plan. If we, as growers, are content to continue a competitive catalog appeal to a limited number of Iris and Peony enthusiasts (members of National Societies and kindred Garden Clubs) then we must all resort to price appeal for business: but, if we as growers, can broaden our field of customers, can interest a large number of persons in appreciating the beauty and ease of cultivation of our favorites, then will merit and demand place a proper price range on each variety. Our problem is not one of trade competition, but it is one of co-operative education.

I can almost hear the united refrain coming in the words of Mack of "The Two Black Crows," "True, brother, true," with the added phrase. "but how educate the public?" Our plan is to try to influence the large nursery and seed firms to sponsor and list only the better varieties (many of our good standard varieties are cheap enough now for this purpose) and most important of all, to discontinue listing outof-date, discarded things. We are making some progress, but the field is large and the workers few. There is ample opportunity for every grower to help in this educational effort.

There is also a marvelous opportunity for education in local display or exhibition gardens. whether they are privately or publicly fostered. Give each of the better Irises, Peonies and Oriental Poppies an opportunity to speak "its own piece" to an interested public, and our limited plantings will not begin to fill the demand. We want to co-operate with growers and dealers in establishing and maintaining artistic display gardens. Choose wisely, plant carefully, cultivate thoroughly and your plants will sell themselves at prices which will bring a nice return on your investment. Remember, we are always ready to co-operate in any movement to bring the better Irises, Peonies and Oriental Poppies to the attention of the great number of persons to whom they are as yet unknown. What can we do to help you start a creditable display or exhibition garden for your section? Our experience, our stock and our advertising helps are available for your use.

\section{Bonnewitz Iris Price List Reheatsal}

\section{ACT II: SCENE I.}

Our first Iris Price List Rehearsal seemed to strike a chord of common interest. Mr. Bonnewitz and I will both appreciate your comments on the varieties appearing in this second act.

AFTERGLOW - We believe this appropriately named variety will be a profitable one both for the grower and the dealer. Unfortunately we will not be able to make spring delivery on it, but we expect to list it in our retail catalog for July delivery at $\$ 0.50$ each. and our regular wholesale price on it will be $\$ 0.25$. We hope to be able to offer a discount on large quantities. It can be ordered by dealers, in small quantities at $\$ 0.25$ each

ALCAZAR-We will list this splendid, large. tall Iris at $\$ 0.35$ in our retail catalog, and dealers can order it from us in any quantity at $\$ 0.15$ each. Of course, there will be a still lower price in quantity, but at a $\$ 0.35$ retail price, it will pay the dealer a good profit even if purchased in small quantities.

ARCHEVEQUE-This Iris will appear in our retail catalog at $\$ 0.35$ each, and dealers can order it in any quantity at $\$ 0.15$ each. It is not large, but in color and quality it approaches the very best Irises upon the market and as it is both beautiful and prolific, it will probably be a splendid variety for both grower and dealer. 
AZURE-This excellent Iris approaches Dominion in color and quality more nearly than any other low priced Irises. It however, lacks the size of Dominion. We will offer it in our retail list at $\$ 0.50$ each, and dealers can order it from us at $\$ 0.25$ each.

BALLERINE-This is a most beautiful Iris, but it has been a very unreliable grower in our garden. We will list it again at $\$ 1.00$, and we may have some stock to deliver at $\$ 0.50$ each, wholesale.

BLACK PRINCE-(Sny .Black Knight). We have had a most disastrous experience with this variety. It has proven a most unreliable grower for us. We will probably sell a few rhizomes at $\$ 1.00$ retail, but we cannot advise its purchase.

CECIL MINTURN-For March delivery we expect to offer this variety at $\$ 0.75$ each, retail, and $\$ 0.35$ each, wholesale. For July we hope to have enough stock of it so that we can make a retail price on it of $\$ 0.50$ and a wholesale price of $\$ 0.25$.

CHASSEUR-For July delivery we expect to offer this variety at $\$ 3.00$ each, retail, and $\$ 1.50$ each, wholesale. We will be interested in knowing what other growers think of it.

CLIO-This is one of the most satisfactory Irises in our garden, very much like $\mathrm{Pal}$ lida Dalmatica. Our price, both spring and fall, will be $\$ 0.35$ retail and $\$ 0.15$ wholesale. We do not hesitate to recommend it. Its bloom is not as large as Princess Beatrice but its growth, its habit, its foliage and its vigor are unsurpassed.

CLUNY - This very tall growing Iris has been satisfactory with us in every respect. We will offer it both spring and fall at $\$ 0.50$ each retail, and $\$ 0.25$ wholesale.

CORRIDA-This is one of the very best blue landscape Irises in the world. We have a nice stock of it and will offer it both spring and fall at $\$ 0.50$ retail and at $\$ 0.25$ wholesale.

DALILA - This variety has always been a favorite in our garden, and our stock is now large enough to offer it both spring and fall at $\$ 0.35$ each, retail, and $\$ 0.15$ each, wholesale. Bound to be a winner when it becomes better known.

DEUIL DE VALERY MAYET-For the first time we are now ready to offer this splendid red-purple Iris for spring at $\$ 0.75$ each, retail, and $\$ 0.37 \mathrm{each}$, wholesale.

DIADEM-We believe this Iris is a good one for both the grower and tise dealer. We know of no other Iris with exactly th same colors. Our price both, spring an fall, will be $\$ 0.50$ retail and $\$ 0.25$ whole sale.

DOROTHEA K. WILLIAMSON-This is a beardless variety which transplants much better in the spring than at any other tim? We have a nice stock of it and offer it at $\$ 1.00$ retail and at $\$ 0.50$ each to the trade. We can quote a very attractive prize on large quantities.

DUKE OF BEDFORD-(Dominion Seedling) We expect to offer this splendid Iris for July delivery at $\$ 10.00$ each, retail, and $\$ 5.00$ wholesale.

ECKESACHS-Our stock of this Iris from Germany is now large enough that we will offer it for either spring or fall delivery at $\$ 0.75$ retail and at $\$ 0.35$ each to other dealers or growers.

ECLAIREUR-For the very first time we will offer this French Iris at $\$ 1.00$ each, retail. and at $\$ 0.50$ each wholesale. Delivery either in March or July.

E. H. JENKINS-Our price on this well knowr Iris will be $\$ 0.75$ each, retail, and $\$ 0.35$ each, wholesale. Delivery either in March or July.

GOLD CREST - We will list this splendid Iris which retains its popularity better than any other variety in England at $\$ 0.50$ each, retail, and at $\$ 0.25$ each, wholesale.

IMPERATOR-We are very glad that we will be able to list this bright red-lilac Iris for either spring or fall delivery at $\$ 2.50$ retail and $\$ 1.25$ each, wholesale.

IRIS KING-This standard Iris will be offered for either spring or fall delivery at $\$ 0.35$ each, retail, and $\$ 0.15$ each, wholesale.

ISOLINE-This very large lilac-pink increases every year in popularity. We will offer it for spring delivery at $\$ 0.35$ each, retail, and at $\$ 0.17$ each, wholesale.

JUNIATA-Although Mr. Farr offered this Iris to the trade over ten years ago, it retains its popularity. We will list it at $\$ 0.35$ each, retail. and at $\$ 0.15$ each, wholesale. There will, of course, be a discount for large quantities.

LA BLUET - A landscape variety in class with Bluet. For the very first time we will offer this Iris at $\$ 0.50$ each, retail, and at $\$ 0.25$ each. wholesale, for either spring or fall delivery.

LOHENGRIN-On account of its strong stems this splendid lilac-pink or lilac-blue landscape Iris retains its great popularity. The price on it will be $\$ 0.35$ each, retail, and 
$\$ 0.15$ each, wholesale, for either spring or fall delivery, discount on very large quantities.

MME. CHOBAUT-For July delivery we expect to offer this splendid Iris at $\$ 0.50$ retail, at $\$ 0.25$ each, wholesale. We anticipate a very large demand for it.

MAJESTIC-(Dominion Seedling). We believe this is the best value among the Dominion Seedlings, and for both spring and fall we will offer it at $\$ 10.00$ each, retail, and $\$ 5.00$, each, wholesale. It approaches Duke of Bedford in quality, and we have sometimes thought it was even superior to that variety.

MA MIE-This Iris approaches Ann Farr in quality, and we are glad to offer it at $\$ 0.35$ each, retail, and $\$ 0.17$ each, wholesale.

MARJORIE TINLEY-We find that our stock of this Iris from England is now large enough to list it at $\$ 5.00$ each, retail, and $\$ 2.50$, each, wholesale, for spring delivery.

MARY GIBSON-We are sure that many growers will now be glad to know that we will offer this snlendid Iris at $\$ 7.50$ retail, and at $\$ 3.75$ each, wholesale, for spring delivery.

MIRANDA-For both spring and fall we will list this excellent Iris at $\$ 0.50$ each, retail, and at $\$ 0.25$ each, wholesale. We anticipate a good demand for it.

MOONLIGHT-For spring we will offer a very few rhizomes of this variety at $\$ 7.00$ retail, and at $\$ 3.50$, wholesale. An outstanding Iris.

MONS. O. PERTHUIS-Our stock of this splendid purple Iris has increased enough to list it for spring delivery at $\$ 1.00$, and at $\$ 0.50$ each, wholesale. In good seasons it shows Dominion quality, although it has no Dominion blood in it.

PALLIDA DALMATICA-This is one of the most satisfactory Irises in cultivation. We will list it for spring and fall delivery at $\$ 0.35$ each, retail, and at $\$ 0.15$ each, wholesale.

?ARC DE NEUILLY - We have made a very extensive planting of this variety for fall delivery and we expect to offer it at $\$ 0.35$ each, retail, and at $\$ 0.15$ each, wholesale. It is one of the excellent purple Irises which can be sold at a reasonable price.

PEAU ROUGE-We are sure that many growers and dealers will be glad to know that we will list this variety at $\$ 3.00$ retail, and $\$ 1.50$ wholesale, for delivery either in the spring or fall.
PHYLLIS BLISS-We are sorry that we cannot offer this fine Iris for spring delivery, but we will list it for July delivery at $\$ 1.00$ retail, and $\$ 0.50$ wholesale.

PIONEER-We will list this variety at $\$ 5.00$ each, wholesale. Our retail price on it will be $\$ 10.00$ each. Something new and outstanding in color.

POCAHONTAS-This light colored Iris is in a class with Anna Farr and Ma Mie and we will offer it at $\$ 0.35$ each, retail, and at $\$ 0.15$ wholesale price. Either spring or fall delivery.

QUAKER LADY-We regard this variety as one of the most successful and useful Irises in cultivation and we will offer it for both spring and fall delivery at $\$ 0.35$ each, retail, and $\$ 0.15$ each, wholesale. We will have an attractive quantity price.

RED RIDING HOOD-We like this pink-lilac very much. It is in a class with Powhatan, which we are told was used so extensively in Burbank's California garden. We will offer Red Riding Hood at $\$ 0.35$ each, retail, and at $\$ 0.15$ each, wholesale. Small, but outstanding in color.

RHEIN NIXE-This is one of the best of our cheaper standard Irises, and we will offer it at $\$ 0.35$ each, retail, and $\$ 0.15$ wholesale.

ROSEWAY-This is an excellent lilac-pink landscape Iris and we will offer it at retail at $\$ 0.50$ each, and at wholesale at $\$ 0.25$ each, with a discount, of course, for large quantities.

SHERWIN WRIGHT-We intend to offer this yellow Iris at $\$ 0.35$ each in our fall retail catalog and we will sell it to the trade at $\$ 0.17$ each. It is still very scarce in the wholesale market. We purchased excellent rhizomes of it last year from the Pfeiffer Nurseries, Winona, Minnesota. Undoubtedly other growers can replenish their stock from this same source.

\section{Everyone a Bargain}

O. M. Pudor, of Puyallup, Washington, is offering for March and April delivery, Alcazar at $\$ 10.00$ per hundred, Medrano at $\$ 15.00$ per hundred, Opera at $\$ 17.50$ per hundred, Seminole at $\$ 15.00$ per hundred, Siberica Emperor at $\$ 8.00$ per hundred. Everyone of these varieties are outstanding in quality and in our opinion are splendid bargains at the prices quoted. 